Published in European Romantic Review, 21 (2010), 589-600. Reprinted in Thomas Pfau and Robert Mitchell (eds.), Romanticism and Modernity (New York: Routledge, 2012), chap. 10. Please cite one of the published versions.

\title{
THE VERY MODEL OF A MODERN EPIC POEM
}

\section{Nicholas Halmi}

University of Oxford

\begin{abstract}
An epic-length poem without a determinable plan, and therefore remarkably accommodating of contingency, Byron's Don Juan is founded on a distinctly modern understanding of reality as a subjectively realizable potentiality. But just as traditional and novel literary forms can coexists with each other, so can existing and emergennt concepts of reality, however uneasily. In Don Juan the tension between this new concept of reality and that presupposed by the theory of artistic mimesis manifests itself in Byron's flouting of the same epic conventions to which he professes his adherence.
\end{abstract}

Writing in her diary on 8 August 1918, Virginia Woolf analyzed her response to Don Juan. She attributed her pleasure in reading it to the receptiveness of its form to contingencies of content: "It is the most readable poem of its length ever written, I suppose; a quality which it owes in part to the springy random haphazard galloping nature of its method. This method is a discovery in itself. It's what one has looked for in vain-a[n] elastic shape which will hold whatever you choose to put into it. Thus he could write out his mood as it came to him; he could say whatever came into his head" (180-81). While acknowledging the difficulty of emulating Byron, for such "free \& easy things" required skill and maturity to be executed successfully, Woolf nonetheless insinuated that the artistic possibilities of the poet's "method" had not been exhausted in Don Juan. Yet exactly what appealed most to Woolf about the poem has frustrated other readers most. If its expansiveness suggested to the novelist a model for the representation of thought and experience, it has also presented to critics an impediment to assessment of the poem itself.

Considered in the most general terms, this impediment consists in the poem's selfreflexive non-conformity to generic expectations. In striking contrast to The Prelude, which, for all its appropriations from Paradise Lost, never explicitly refers to itself as an epic poem, Don Juan calls itself an epic or calls attention to its use of epic conventions on more than a dozen occasions, and thus positively invites readers to assess it in these terms. Now genres may be critical constructs of limited value in the description of literary works: whether we classify Don Juan as a modern epic (McGann xii-xiii; Reiman), a comic epic (Rutherford 141), a mock-epic (Robertson 321-37), an epic of negation (Wilkie 188-226), an anti-epic (Lauber), an epic satire (Beaty 138-46), an ironic epic romance (Mellor 59), or a versified picaresque novel (Boyd 59; Kroeber 164) —or indeed we insist, like Shelley, that it is "totally of its own species" and cannot be classified otherwise at all (666; cf. Bostetter 12)-we establish nothing objective about the poem. But rather as, according to Gombrich's theory of pictorial representation, the artist relies on conventional conceptual schemata to give order and coherence to the manifold of visual experience (76-78), so the critic relies on conventional generic categories to organize the interpretation of individual parts or aspects of a work (Hirsch 222) and, no less importantly, to contain the overall scope of interpretation (Fowler 259). The importance of this process can most easily be seen where the relation of a 
work to a generic context is implicit, as in Barbauld's "Washing-Day," which makes ironic use of the conventions of epic poetry to legitimize women's domestic experience as a poetic subject. Without knowing those conventions, we could hardly explain the force of Barbauld's invocation of a gossipy "domestic Muse" (4).

A writer's ironic or contestatory relation to a gene need present no interpretive obstacle so long as it presupposes the stability of the conventions identified with that genre. Pope's use of divine "machinery" and martial rhetoric in The Rape of the Lock is readily understood to be directed not against the classical epic but against the families whose dispute occasioned the poem. The mockery of Pope's mock-heroic consists in the disproportion between its trivial subject-matter and its dignified formal attributes. But that, in eighteenthcentury England, a given subject could be recognized as inappropriate to the epic, and its presentation according to the genre's conventions as therefore either deliberately satirical or aesthetically mistaken, was itself owing largely to Milton. Appealing to the inherent dignity of his subject, "sufficient of it self to raise / That name [heroic]" (9.43-44), Milton had expanded the conception of epic decorum, which Renaissance literary theory defined almost exclusively in formal terms. What he came to understand, "long choosing, and beginning late," is that the epic status of a poem depended even more on the poet's choice of subject than on his adherence to aesthetic principles exemplified by Homer and Virgil and codified after Aristotle and Horace (Teskey 141-42).

If the resultant redefinition of heroic poetry, articulated in the invocation to book 9 of Paradise Lost, suited the purposes of Pope's satire, it also arguably discouraged Wordsworth from accepting, let alone publishing, The Prelude as an independent poem: his anxiety that it was "a thing unprecedented in Literary history that a man should talk so much about himself" (586; 1 May 1805) betrays an identification with Milton rather than Rousseau and the sense that a genuine epic theme was "Man, Nature, and Society" (Preface to The Excursion) rather than the growth of a poet's mind. As the potential epic subjects he listed in The Prelude itself (1.159-235) indicates - a striking parallel to Milton's well-known list of tragic themes in the Trinity Manuscript (Works 18:228-44) -Wordsworth was preoccupied with the thought that the "beauteous Fabric" of epic would appear "Shadowy and unsubstantial" $(1.227,229)$, which is to say self-mocking, without a correspondingly elevated subject. In a sense, then, Wordsworth was the victim as well as the beneficiary of Milton's conviction that epic subjects are not made but born. Francis Jeffrey's hostile review of the epic-length poem he did publish, The Excursion - albeit explicitly as "a portion" of the larger Recluse - may have confirmed Wordsworth's earlier intimation that not only would he have, like Milton, to find a subject adequate to the form, but his eventual choice would be judged against Milton's. For precisely the disparity between the content and the form of The Excursion, "a few very simple and familiar ideas" presented in "long words, long sentences, and unwieldy phrasesand such a hubub of strained raptures and fantastical sublimities" (4), was a central point of Jeffrey's contention with Wordsworth.

Interestingly, however, Byron criticized The Excursion more nearly on its own terms. Both in a letter of 30 October 1815 to Leigh Hunt (BLJ 4:324-25) and in the Dedication to Don Juan (which, having been published only in 1832, Wordsworth may never have read), Byron objected specifically to Wordsworth's metaphysical pretensions:

And Wordsworth, in a rather long 'Excursion', 
(I think the quarto holds five hundred pages)

Has given a sample from the vasty version

Of his new system to perplex the sages:

'Tis poetry - at least by his assertion,

And may appear so when the dogstar rages;

And he who understands it would be able

To add a story to the Tower of Babel. (st. 4)

Rejecting the very notion of a philosophical poem, with its implied claim to a totalizing systematicity, Byron did not address the epic form of The Excursion: if the basic premise of the content is absurd, the aesthetic appropriateness of its treatment is irrelevant. But he did have to confront the question of form in his own survey of human society. And whereas Wordsworth, who accepted Paradise Lost as the normative embodiment of epic conventions in English, sought a subject worthy of his poetic ambitions, Byron sought a form worthy of his conception of reality.

I have said that critics use genres as conceptual schemata to organize their interpretations, but it will be evident from the examples just discussed that this process largely involves recognizing the genres that the authors themselves used to structure their works, to relate them to existing literature, and not least to guide their reception. If pictorial representations emerge from what Gombrich calls artists" "correction" of their initial schemata, then literary works and their interpretations emerge from an analogous kinds of refinement of generic conventions. Of course, being human constructs, genres are mutable and can be transformed by the very works whose creation they enable: indeed it was part of Byron's genius, no less than of Milton's, to recognize and exploit this fact for his own artistic purposes. But because, by permitting the comparison of works of different times, genres offer the prospect of transhistorical understanding and judgment, concessions of their own historicity risk impairing, or even undermining, their efficacy. Thus Fowler observes that historical research and imagination may be required to reconstruct generic conventions as earlier writers understood them (261): before readers can refine their interpretations, in other words, they must recognize how writers refined their original generic concepts. And such was the cultural authority of the classical exemplars of epic, at least from the sixteenth century into the eighteenth - and let us recall that Dr. Johnson denied Paradise Lost the palm of the greatest epic only because it was not the first (295) - that the accommodation of later works by theoretical accounts of the genre proved to a highly contentious issue.

To an extent, as I hope to elaborate elsewhere, Byron's (facetious) rejection of episodic narrative ("The regularity of my design / Forbids all wandering as the worst of sinning," 1.7) and (perhaps more earnest) insistence on the historicity of his subject-matter ("'tis the part / Of a true poet to escape from fiction," 8.86) reproduces the arguments, in Italian Renaissance epic theory, of the Tassisti, who valued narrative unity and verisimilitude, against those of the Ariostisti, who favored narrative variety and imaginative fertility (see Javitch; Weinberg 991-1073). This prolonged debate, prompted by the recognition that the popularity of Ariosto's Orlando furioso (a work Tasso did not consider a genuine epic) might radically alter the basic idea of the genre, betrays an underlying anxiety about the ongoing transition from a manuscript to a print culture (Teskey 135-36). Similarly, the equally prolonged neoclassical effort, led by René Le Bossu in France and Dryden in England (see 
Swedenberg), to codify the principles of the plot, language, subject-matter, and moral purpose of epic - in effect a rationalist construction of the literary genre most strongly identified with antiquity - betrays an anxiety about the self-assertion of an emergent modernity as a dissociation from the past. It is no accident that the development of neoclassical epic theory coincides, in the late seventeenth century, with the Querelle des anciens et des modernes, a general consequence of which was to foster an historicist understanding of cultural works and a relativist understanding of taste (see Patey).

Writers tend to address genre as a theoretical issue precisely when they realize that the existing conventions no longer provide an adequate basis for what they want to achieve artistically - when their conceptual schemata, in other words, can no longer be corrected easily - and in this respect Byron was no different from Tasso, Milton, or for that matter T. S. Eliot, whose review of Ulysses credited Joyce with having discovered a replacement for the exhausted form of the novel (177-78). Though one may question George Ridenour's claim that Don Juan shares with Paradise Lost a central concern with the loss of innocence, he is surely right that "Byron is attempting as radical a redefinition of the nature of epic and the epic hero as was Milton" (92). Just as Milton was "Not sedulous by Nature to indite / Warrs, hitherto the only Argument / Heroic deem'd" (9.27-29), so Byron is not prepared to sanitize or justify the brutality of war by appealing to conventional notions of heroism: when he announces, in the first stanza of the first canto of the poem, "I want a hero: an uncommon want, / When every year and month sends forth a new one," he is not only condemning the moralistic cant by which his own age disguises its blood-lust from itself, but suggesting "that the traditional heroic poem compromises itself morally by its apparent glorification of bloodshed" (Ridenour 91). Introducing the narrative of the battle of Ismail in canto 7, Byron trenchantly and explicitly ironizes Spenser's affirmation that "Fierce warres and faithfull loues shall moralize [his] song" (1.proem.1):

'Fierce loves and faithless wars'- I am not sure

If this be the right reading-'tis no matter;

The fact's about the same, I am secure. ... (7.8)

Significant as it is, Byron's critique of the epic's traditional martial theme is but one manifestation in Don Juan of his self-reflexive engagement with the genre. When, in a letter of 6 April 1819 to John Murray, he disavows any intention of producing "what you call a 'great work' an Epic poem I suppose or some such pyramid" (BLJ 6:105), he is responding specifically to his publisher's insinuated preference for a long poem that would be inoffensive to and popular with the book-buying public (Murray 267). In the poem itself he answers Murray more comprehensively - and more ambiguously - by honoring epic norms as much in the breach as in the observance. If Renaissance and neoclassical epic theory defended an ordo obliquus, violating chronology for the sake of narrative coherence, Byron, or at least his narrator, rejects it for exactly the same reason:

Most epic poets plunge in 'medias res',

(Horace makes this the heroic turnpike road)

And then your hero tells, whene'er you please,

What went before. ...

That is the usual method, but not mine- 
My way is to begin at the beginning;

The regularity of my design

Forbids all wandering as the worst of sinning. $(1.6,7)^{2}$

At the end of the canto, he no sooner affirms the authority of "Aristotle's rules, / The vade mecum of the true sublime" (1.201), than promises to undermine it, the affirmation and contradiction equally jesting:

I'll write poetical commandments, which

Shall supersede beyond all doubt all those

That went before ...

I'll call the work 'Longinus o'er a Bottle,

Or, Every Poet his own Aristotle.' (1.204)

While distinguishing himself from his "epic brethren gone before" on the grounds that his "story's actually true" (1.202) — a claim that neglects Tasso's vindication of epic subjects taken from history, as in his own Gerusalemme liberata, rather than invented (34-40)Byron nevertheless chooses a purely legendary figure as his protagonist, and then proceeds to ironize that figure in turn by representing him as more seduced than seducing. When the poem manages (by its own lights) to adhere to tradition, it can do so excessively, betraying either a want of taste_- "I feel this tediousness will never do_-/'Tis being too epic" (3.111; cf. 3.97)—or a want of judgment:

My poem's epic, and is meant to be

Divided in twelve book; each book containing,

With love, and war, a heavy gale at sea,

A list of ships, and captains, and kings reigning ...

After the style of Virgil and of Homer,

So that my name of Epic's no misnomer. (1.200; my emphasis)

In canto 8, before dispatching Juan to St. Petersburg to deliver news of the battle of Ismail to Catherine the Great, Byron stops to congratulate himself for having realized the intention proclaimed at the poem's beginning:

Reader! I have kept my word, - at least so far As the first Canto promised. You have now

Had sketches of love, tempest, travel, war-

All very accurate, you must allow,

And Epic, if plain truth should prove no bar;

For I have drawn much less with a long bow

Than my forerunners. Carelessly I sing,

But Phoebus lends me now and then a string

With which I still can harp, and carp, and fiddle. . . (8.138-39)

Such "carelessness" is nowhere better demonstrated than in the invocation, which, apart from appearing only after two cantos, is the most perfunctory in the history of the epic: "Hail, Muse! et cetera" (3.1). ${ }^{3}$

It may be tempting to conclude from Byron's evident refusal to take the genre itself, and hence his own claims to its status, entirely seriously that "Don Juan should be regarded as a vast literary joke" (Marshall 177), or to take his description of the poem as "this Epic 
Satire" (14.99) as licence to subordinate consideration of the poem's generic antecedents to that of its historical referents: when the classification epic is demoted to an adjective, the noun satire assumes precedence. Hence Jerome McGann's insistence that the question of whether or not the poem is a an epic is "semantic and perhaps philosophical, but not scholarly" (xii). Don Juan is a true one because "Byron wanted it to be thought of as such, and because the consensus of history has agreed." But in dismissing the poem's generic classification as a "pseudo-problem," McGann concedes the historicity of genres, which is to say their adaptability: "The mock-heroic tradition, especially in the eighteenth century, also created certain possibilities for the true epic, as Don Juan shows; and the entrance of Don Juan into the epic tradition had an important effect upon later poems, like the Cantos." To that extent, then, genre remains a real problem in literary history, which is why the genre of Byron's long poem has preoccupied critics. In response to McGann, Donald Reiman affirms that the Don Juan "seems to fulfill the conditions of modern epic" through its encyclopedic presentation of late-Enlightenment European civilization (594). Byron himself told Thomas Medwin, "If you must have an epic, there's Don Juan for you. I call that an epic; it is an epic as much in the spirit of our day as the Iliad was in Homer's" (164). But why should the age demand an epic in the first place? And why, if Byron was critical of the traditional epic, should he have repeatedly encouraged his long poem to be compared with it?

It has long been recognized that the epic, as the longest and most inclusive of poetic forms, is capable of assimilating characteristic features of other genres. Thus Milton, for whom choosing the Fall of man as a poetic subject also entailed choosing between tragedy and epic as the most appropriate form for that subject, was able to incorporate the former into the latter: "I now must change / Those Notes to tragic" (9.5-6). But even if, in Byron's case, his sense of the insufficiency of pastoral, romance, and satire individually led him almost by default to the epic, in which he could continue to exploit those genres while surpassing their limitations, this would not explain his contentious relation to epic itself. What is surprising is not that he should subvert the form, but that he should think it worth the trouble of subverting as part of "a totally demythologized presentation of what he sees, thinks, creates" (Curran 197).

E. D. Hirsch explains Byron's paradoxical relation to generic convention as assisting both the creation and the reception of Don Juan:

When Byron said, 'My poem's epic' he was relying on the reader's knowledge of traditional epic conventions, and he was also relying on traditional episodes [e.g., the shipwreck in canto 2] as a schema for his own imagination. ... Older genre conventions both guided Byron's invention and nourished it, but it is obvious that the genre idea of Don Juan is Byron's alone and is a new kind that had never existed before. One reason Byron felt obliged to lard the poem with so many explicit explanations of what he was up to was that his readers needed signposts which he did not have to provide in the somewhat more traditional genre of Childe Harold. (106-7)

However plausible in itself, this explanation leaves unexplained its implication, first, that genres change in response to historical contingencies, and second, that older generic forms are indispensible in the development of new ones. Generalizing from Byron's own critique of the representation of war in epic tradition, we might say that the inadequacy of an established 
literary form, as a model to be emulated or "corrected" in the sense discussed earlier, becomes manifest when it can no longer be reconciled to perceived reality, that is, when the conception of reality on which the original form is founded and to which it gives expression has altered sufficiently radically to expose the form itself as being an historical artifact. So before we can address the question of form directly, we must address that of conceptions of reality.

The qualifying plural is necessary because the emergence of a new concept of reality does not necessarily entail the suspension or suppression of an existing one. As Hans Blumenberg has argued, the dominant artistic theory in the Western aesthetic tradition, that of imitation, presupposes an ancient understanding of reality as both exemplary and complete (15); but the theory has never been simply abandoned as alternative concepts of reality have developed. Even now art is likely to be understood primarily in terms of imitation, regardless of whether any imitation is recognized in a particular work: to speak of "nonrepresentational" art is to assume a prior reality of which art could be representational; to speak of "abstract" art is to assume the prior existence of the concrete. To be sure, the idea of imitation can itself undergo transformation, as it did in Karl Philipp Moritz's aesthetic theory, which defined artistic activity itself (as an imitative of God's creation of the world) rather than the finished artwork as mimetic, and again in Coleridge's distinction between imitation and copy, which privileged the reproduction of the inner organizing structures of phenomena over that of their outward forms. But such transformations - which may prove on closer inspection to be quite superficial, barely disguising a fundamental conceptual discontinuitytend to confirm that the inherited idea is too powerful to be dismissed outright, let alone forgotten. I shall return to this point presently.

A comparable burden of inheritance characterizes literary forms, which is why some continue to be used long after what one might have expected to be their "best before" dates. Epic, indeed, is an excellent example. For notwithstanding the critical commonplace that the novel succeeded the epic poem as the preferred and representative long narrative form in the modern age — "the epic of the godforsaken world," in Lukács's famous phrase (87)—poems calling themselves epics or otherwise recognizably aligned with the epic tradition continued to be written well after the novel had ceased to be a novelty. Stuart Curran (158-79) and Herbert Tucker have demonstrated that early nineteenth-century Britain was extraordinarily productive of epics, would-be epics, and epic-like poems, by no means limited to the "epic from Bob Southey every spring" (Don Juan 3.97), even if many of these poems recommended themselves as little to contemporary readers as they do to us.

Franco Moretti attributes the persistence of epic, as a recognizably distinct form, precisely to its being a forma ereditata, "inherited form": "In the face of such a precedent, modern literature could certainly, in theory, have contented itself with the narrower spatial and temporal scope [spaziotempo] of the novel, but it would then have conceded its own inferiority with respect to the greatness of the past" (34). Although the early modern novel, owing to its capaciousness, could stake a claim to be the inheritor of the epic tradition - and indeed the self-reflexive opening chapter to each volume of Tom Jones did so-it was still constrained by its being a fundamentally bourgeois form, concerned with human intersubjective relations. Thus the rise of the novel did not foreclose the possibility of the epic. 
At the same time, however, those conditions that were favorable to novels were not necessarily also conducive of epics. To remain viable, as opposed to merely possible, epics had to adapt to modernity. According to Moretti, the plausibility of whose argument depends partly on one's acceptance of his broad definition of epic, such adaptation manifested itself above all in irony, specifically (though by no means exclusively) an ironic relation to epic conventions themselves. "Irony," Moretti writes, "seems to be the ideal strategy for preserving rather than losing the 'unitary vision of the world' [embodied in traditional epics]: it is a formidable defense mechanism, which eludes the double bind of the hereditary form and permits the epic to survive in the new world" (36). But the survival is profoundly ambivalent. Epic repeats itself as farce, more in the hope of avoiding complete failure than of inaugurating a new form (un modo di sottrarsi a un fallimento, piú che l'inizio di una forma nuova). What we discern in the modern epic, therefore, is a "sign of great intelligence- but an unfree intelligence, which has assigned itself an unrealizable task and strains [fatica] under the tremendous pressure of history" (37). Hoc opus, hic labor est.

In common with what Moretti calls opere mondo, "the geographical referent of which is no longer the nation-state but a larger entity: a continent or the world-system in its entirety [il sistema-mondo nel suo insieme]," Don Juan exhibits a cultural and linguistic expansiveness that might be called encyclopedic. Moretti himself (whose examples include Faust, Ulysses, and One Hundred Years of Solitude) uses this term in a sense related to Northrop Frye's conception of the anatomy or Menippean satire: loosely structured, learned, ironic, highly self-conscious. But the term applies to Byron's poem equally in a sense identified by Tilottama Rajan as distinctively Romantic: manifesting, in a formal openness or resistance to closure, a recognition of the inevitable "incompleteness of knowledge" (6). In contrast to the conventional encyclopedia, which presents itself as the compendium of a finite body of knowledge, complete within its self-imposed limits of definition, the Romantic one privileges the innerconnectedness and developmental potential of knowledge. And just as the Romantic encyclopedia (of which Rajan adduces Novalis's Allgemeines Brouillon and Coleridge's notebooks as illustrations) appears maddeningly fragmented and unsystematic when viewed from the perspective of the normative model, so Don Juan, with its digressiveness, appropriation of multiple generic models, and lack of narrative telos appears thoroughly unsatisfactory when viewed from the perspective of the traditional epic — or for that matter from that of the systematic treatise. When Eric Strand faults McGann for trying to make a virtue of the poem's episodic quality (506), he merely betrays, like so many earlier critics, his wish that the poem were other than it is: in this case that it offered a more consistent critique of capitalism.

What Don Juan shares with the Romantic encyclopedia as Rajan describes it is a basic epistemological modesty. By this I mean not so much Byron's disinclination to enter into traditional metaphysical questions, like that about the immortality of the soul: "Why will I thus entangle / Myself with metaphysics?" (15.90; cf. 11.4). Rather, I mean his skepticism towards all manner of dogmatic understandings of reality. This skepticism manifests itself discursively within the poem, as Terence Allan Hoagwood as shown (70-72), in ostentatious dismissals of the desire for certitude and refusals to decide among contradictory alternatives:

whene'er I have expressed

Opinions two, which at first sight may look 
Twin opposites, the second is the best.

Perhaps I have a third too in a nook,

Or none at all — which seems a sorry jest;

But if a writer should be quite consistent,

How could he possibly show thing existent?

If people contradict themselves, can I

Help contradicting them, and every body,

Even my veracious self?-But that's a lie;

I never did so, never will- how should I?

He who doubts all things, nothing can deny. . . (15.87-8)

But there are also, I suggest, formal manifestations of Byron's skepticism in the structure, diction, and referential range of the poem: that is, in its narrative freedom and inconclusiveness (as a constitutive element of the plot, as opposed to the contingent fact of the poem's having been left unfinished); its mixture of figures and events historical, invented, and appropriated from existing literature; its constant shiftings in tone and rhetorical register (a feature for which the closing couplet of the ottava rima stanza is particularly suited); its multifaceted allusiveness comprehending antiquity, contemporaneity, and much in between. Like Coleridge's project for an encyclopedia in which the catch-all category "miscellaneous" sought to incorporate into the totalizing form of a rational classification of knowledge the possibility of admitting new facts and alternative interpretations (Halmi 131-33), at the very risk of undermining the original principles of classification, Don Juan adapts its various literary models and the discipline of an imported stanzaic form for the purpose of an extraordinary capaciousness of view, and precisely in the renunciation of any pretension to una visione unitaria del mondo. Thus the poem's most obvious departure from epic tradition, its confessed lack of a narrative plan, is a constitutive element of its structure and the source of its distinctiveness: "I meant to make this poem very short, / But now I can't tell where it may not run" (15.22), for "The plan at present's simply in concoction" (12.87). ${ }^{4}$ In his best, if unconscious, joke at Wordsworth's expense, Byron declares the first twelve cantos "Preludios" to the poem itself:

But now I will begin my poem.--'Tis

Perhaps a little strange, if not quite new,

That from the first of Cantos up to this

I've not begun what we have to go through. (12.54)

Even the poem's proclamations of its epic status are typically expressed in the future tense or as promises, as if to emphasize that its relation to the form is not fixed but constantly developing: "My poem's epic, and is meant to be . .." (1.200); "And I shall take a much more serious air" (14.99); "this Epic will contain ..." (16.3). To that extent, McGann is surely right to insist that "Byron's world is not a system; it is a network of systems and orders, some of which may overlap, some of which may not" (103).

What I have called Byron's epistemological modesty is appropriate to that concept of reality which Blumenberg associates generally with modernity: reality as the actualization of a context that cannot be determined a priori. Reality is now understand not as a property of objects, but as a potential that can be realized only subjectively, or intersubjectively, and 
hence always partially: reality is always $a$ reality, which is why it is typically linked with a possessive adjective. Because it allows for the possibility of novelty, this concept of reality finds its logical aesthetic expression, Blumenberg argues, in the literary form whose very name in English announces its newness, the novel. But how can the novel be understood to represent a reality that it itself creates by realizing a particular context out of infinite potential contexts? Representation, after all, implies a determinable correspondence to exactly what the concept of reality as context denies: something existing and transcendentally guaranteed. Strictly speaking, then, reality in the modern concept cannot be represented, only realized: novels thus are the worlds they purport to represent. So when Byron, for his part, promises to hold up for view "the Nothingness of life" (7.6), he touches - I do not say consciously, of course - on a basic paradox both of the novel, as Blumenberg understands the form, and of his own poem, which is a dependence on a tradition that the form itself negates. Just as inherited aesthetic forms are not abandoned after the original conditions of their development have changed or ceased to exist, neither do inherited understandings of representation as the representation of something anterior.

In Don Juan, I want to propose by way of a necessarily provisional conclusion, the tension between the modern concept of reality implied in the poem's formal openness and its reliance on an older concept of a given and completed reality emerges explicitly in connection with the poem's satirical purposes. ${ }^{5}$ Byron leaves little doubt that he understands satire to consist in the exposure of a disparity between professed norms and actual behaviors:

But now I'm going to be immoral; now

I mean to show things really as they are,

Not as they ought to be; for I avow,

That till we see what's what in fact, we're far

From much improvement with that virtuous plough

That skims the surface, leaving scarce a scar

Upon the black loam long manured by Vice,

Only to keep its corn at the old price. (12.40)

If "Don Juan is the epic for an age of bullshit," as Tucker claims (231), that is because it still assumes there is earth beneath the shit, and that we can recognize the difference between the two when our faces are thrust into them. Or to express this thought in more decorous terms: for the sake of his satire, Byron abandons his epistemological modesty for an immodest truthclaim predicated on a traditional concept of representation and a traditional concept of reality itself. His repeated insistence on the factual accuracy, on the historicity of Don Juan attests to a concern less with the realization of a potential reality than with the resistance, on the part of the English public, to the recognition of an existing reality - their own: "But 'tis as well at once to understand, / You are not a moral people, and you know it / Without the aid of too sincere a poet" (11.87).

Yet even there, in his most naked indictment of those from whom he exiled himself, Byron's comic side, which accepts the contradictions and multiplicity of reality, or realities, asserts itself, as if to acknowledge the futility of his satire. The poem's simultaneous dependence on and rejection of established generic conventions, above all those of the epicthe defined duty of which, from the beginning of critical reflection on the genre, was to tell truth (Xenophanes fr. 11 B 1.19-23, q. in Blumenberg 9 n. 1) -reflect an underlying tension 
between the concepts of reality operative in the poem, one traditional and the other distinctly modern. It is precisely from that unresolved and irresolvable tension that Don Juan emerges as an exemplary expression of the predicaments of modernity.

University of Oxford 
Notes

1. Don Juan is quoted from McGann's edition of The Complete Poetical Works and cited by by canto and line numbers, while Byron's letters are quoted from Marchand's edition of Byron's Letters and Journals, abbreviated in references as BLJ.

2. Byron's reference to wandering and sinning here recalls the Latin errare, which means both "wander" and "err," a bilingual pun that Milton too had deployed in Paradise Lost: "Least from this flying Steen unreign'd . . . Dismounted, on th' Aleian Field I fall / Erroneous, there to wander and forlorne" $(7.17,19-20)$.

3. For a more extensive survey of Byron's use of and allusion to epic conventions in Don Juan, see Wilkie (198-211).

4. On the lack of a plan, see also, e.g., Byron's letter of 16 February 1821 to John Murray: "The 5th. is so far from being the last of D. J. that it is hardly the beginning. . . To how many cantos this may extend-I know not—nor whether (even if I live) I shall complete it" (BLJ 8:78).

5. For a comprehensive of the aims and methods of the satire in Don Juan, see Beaty (chaps. $5-8)$. 
References

Barbauld, Anna Laetitia. "Washing-Day." Selected Poetry and Prose. Ed. William McCarthy and Elizabeth Craft. Peterborough, ON: Broadview, 2002. 144-47. Print.

Beaty, Frederick. Byron the Satirist. Dekalb, IL: Northern Illinois UP, 1985. Print.

Blumenberg, Hans. "Wirklichkeitsbegriff und Möglichkeit des Romans." Nachahmung und Illusion. Ed. H. R. Jauss. Munich: Eidos, 1964. 9-27. Print.

Bostetter, Edward, ed. Twentieth-Century Interpretations of Don Juan. Englewood Cliffs, NJ: Prentice-Hall, 1969. Print.

Boyd, Elizabeth. Byron's Don Juan. New Brunswick, NJ: Rutgers UP, 1945. Print.

Byron, George Gordon, Lord. Byron's Letters and Journals. Ed. Leslie Marchand. 13 vols. London: Murray, 1974-94. Print.

-. Don Juan. Vol. 5 of The Complete Poetical Works. Ed. Jerome McGann. 1986. Oxford: Clarendon, 1992. Print.

Curran, Stuart. Poetic Form and British Romanticism. New York: Oxford UP, 1986. Print.

Eliot, T. S. "Ulysses, Order, and Myth." Selected Prose. Ed. Frank Kermode. London: Faber, 1975. 175-78.

Fowler, Alastair. Kinds of Literature: An Introduction to the Theory of Genres and Modes. Oxford: Clarendon, 1982. Print.

Gombrich, E. H. Art and Illusion: A Study in the Psychology of Pictorial Representation. 5th ed. London: Phaidon, 1977. Print.

Halmi, Nicholas. "Coleridge's Most Unfortunate Borrowing from A. W. Schlegel.” British and European Romanticisms. Ed. Christoph Bode and Sebastian Domsch. Trier: WVT, 2007. 131-42.

Hirsch, E. D., Jr. Validity in Interpretation. New Haven: Yale UP, 1967. Print.

Hoagwood, Terence Allan. Byron's Dialectic: Skepticism and the Critique of Culture. Lewisburg, PA: Bucknell UP, 1993. Print.

Javitch, Daniel. "Italian Epic Theory." The Renaissance. Ed. Glyn Norton. Vol. 3 of The Cambridge History of Literary Criticism. Cambridge: Cambridge UP, 1999. 205-15. Print.

Jeffrey, Francis. Rev. of Wordsworth's Excursion. The Edinburgh Review 24.47 (Nov. 1814): 1-30. Print.

Johnson, Samuel. "Milton." The Lives of the Most Eminent English Poets; with Critical Observations on Their Works. Ed. Roger Lonsdale. 4 vols. Oxford: Clarendon, 2006. 1:242-95. Print.

Kroeber, Karl. Romantic Narrative Art. Madison: U of Wisconsin P, 1960. Print.

Lauber, John. "Don Juan as Anti-Epic.” Studies in English Literature, 1500-1900 8 (1968): 607-19. Print.

Lukács, György. Theorie des Romans. 1920. Neuwied am Rhein: Luchterhand, 1963. Print.

Marshall, William. The Structure of Byron's Major Poems. Philadephia: U of Pennsylvania P, 1962. Print.

McGann, Jerome. Don Juan in Context. London: Murray, 1976. Print.

Medwin, Thomas. Journal of the Conversations of Lord Byron: Noted during a Residence 
with his Lordship at Pisa, in the Years 1821 and 1822. London, 1824. Print.

Mellor, Anne. English Romantic Irony. Cambridge, MA: Harvard UP, 1980. Print.

Milton, John. The Works of John Milton. Ed. Frank Allen Patterson et al. 20 vols. New York: Columbia UP, 1931-40. Print.

Morretti, Franco. Opere mondo: Saggio sulla forma epica dal Faust a Cent'anni di solitudine. Turin: Einaudi, 1994. Print.

Murray, John. The Letters of John Murray to Lord Byron. Ed. Andrew Nicholson. Liverpool: Liverpool UP, 2007. Print.

Patey, D. L. "Ancients and Moderns." The Eighteenth Century. Ed. H. B. Nisbet and Claude Rawson. Vol. 4 of The Cambridge History of Literary Criticism. Cambridge: Cambridge UP, 1997. 32-71. Print.

Rajan, Tilottama. "Philosophy as Encyclopedia: Hegel, Schelling, and the Organization of Knowledge." The Wordsworth Circle 35 (2004): 6-11. Print.

Reiman, Donald. “Don Juan in Epic Context." Studies in Romanticism 16 (1977): 587-94. Print.

Ridenour, George. The Style of Don Juan. New Haven: Yale UP, 1960. Print.

Robertson, Ritchie. Mock-Epic Poetry from Pope to Heine. Oxford: Oxford UP, 2009. Print.

Rutherford, Andrew. Byron: A Critical Study. Edinburgh: Oliver, 1962. Print.

Shelley, Percy Bysshe. The Letters. Ed. Frederick Jones. Vol. 2. Oxford: Clarendon, 1964. Print.

Spenser, Edmund. The Faerie Queene. Ed. A. C. Hamilton. 2nd ed. Harlow: Longman, 2001. Print.

Strand, Eric. "Byron's Don Juan as a Global Allegory." Studies in Romanticism 43 (2004): 503-36. Print.

Swedenberg, H. T., Jr. The Theory of the Epic in England 1650-1800. Berkeley: University of California P, 1944. Print.

Tasso, Torquato. Discourses on the Heroic Poem. Trans. Mariella Cavalchini and Irene Samuel. Oxford: Clarendon, 1973. Print.

Teskey, Gordon. Delirious Milton: The Fate of the Poet in Modernity. Cambridge, MA: Harvard UP, 2006. Print.

Tucker, Herbert. Epic: Britain's Heroic Muse, 1790-1910. Oxford: Oxford UP, 2008. Print. Xenophanes. [Fragments.] Die Fragmente der Vorsokratiker. Ed. Hermann Diels and Walther Kranz. 6th ed. 1951. Berlin: Weidmann, 1966. 1:38-58. Print.

Woolf, Virginia. The Diary of Virginia Woolf. Ed. Ann Olivier Bell. Vol. 1. London: Hogarth, 1977. Print.

Weinberg, Bernard. A History of Literary Criticism in the Italian Renaissance. Vol. 2. Chicago: U of Chicago P, 1961. Print.

Wilkie, Brian. Romantic Poets and the Epic Tradition. Madison: U of Wisconsin P, 1965. Print.

Wordsworth, William. The Excursion. Ed. Sally Bushell, James Butler, and Michael Jaye. Ithaca, NY: Cornell UP, 2007. Print.

—. The Thirteen-Book Prelude. Ed. Mark Reed. Vol. 1. Ithaca, NY: Cornell UP, 1991. Print.

Wordsworth, William, and Dorothy Wordsworth. The Letters of William and Dorothy 
Wordsworth. Ed. Chester Shaver and Alan Hill. 2nd ed. Vol. 1. Oxford: Clarendon, 1967. Print. 